特集 バイオテクノロジーと水処理技術

\title{
欧米諸国におけるバイオテクノロジー開発状況
}

\section{Topics in sewage treament by means of biotechnology in the world}

中 山 大 樹*

バイオテクノロジー，即ち生物利用技術を水処理に 役立てようという研究が世界中で進められているが, 近い将来，水処理技術に革命的な影響を及ぼすととに なりそうなのは，「バイオ」の方では環境毒の生分解 に役立つ微生物の探索ないし育種,「テクノロジー」の 方では, 省エネルギーどてろかエネルギー生産型の 2 次処理技術, 即ち, 下水の直接嫌気処理であろう. 紙 数に限りがあり, 原典の呈示が有益かと思われるので, ての点に的を絞って, 最近の文献に現れた海外の研究 の一端を紹介しよう。

\section{1. 嫌気的 2 次処理技術}

下水処理の第 1 標的はBODであって, BOD除去のた めに莫大な量のエネルギーが投入されている。とてろ が, BODのもとは, 主として有機物, 即ち高エネルギ 一炭素化合物なのだから,「BODエネルギー」を使っ てBODを除去するのが最す合理的であると言えよう.

これに役立つのが，嫌気消化と，それに続くガス化 反応, 主としてメタン発醉であるが, 繁殖が遅い貴重 なメタン菌を使い捨てにしない技術の開発に成功すれ ば，社会的波及効果が絶大である，その為の嫌気的バ イオリアクターの基本的な型は, ほぼ出揃った感があ る.

1) 上向流嫌気性沪床：比重が 1 より大きい沪材を 詰めたシリンダーの下部から原水を入れ，処理水を上 部から流出させる方式である. 消化槽污泥等を加えて 長く運転していると, 汇材の表面が嫌気性生物膜で被 われ，メタンと二酸化炭素を主とするバイオガスが発 生するようになる，1960年代から，硝化液の脱空素用 に研究されていた方式だが, Oak Ridge National Laboratoryから, ANFLOW (anaerobic upflow fixed film bioreactor) の名で, メタン生産を兼稀 た下水の 2 次処理への適用が発表され ${ }^{1}$ 3)，1981年に

\footnotetext{
* 山梨大学工学部環境整備工学科教授

Ohoki NAKAYAMA
}

は，早くあ，そのためのワークショップが開かれてお $り^{4)}$, 化学工業 ${ }^{5)}$, 製薬 ${ }^{6)}$, 革なめし ${ }^{7,8)}$ 廃水, 熱処 理した余剩污泥からの浸出水 $\left.{ }^{9}, 10\right)$, 酸性乳清 ${ }^{11}$ などの 処理に用いられて，その有用性が証明され，ゼラチン を用いた酸生成段階だけへの応用にも成功している ${ }^{12}$.

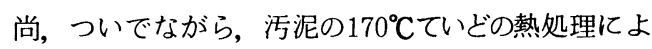
る脱水性向上については，日本であ注目されるように なって来たが, 早くから多くの研究報告が出ている13 23).

さて, ANFLOW法は, 立ち上がりがおそいが, 順 調に動き出せば, ショック・ロード 24), $\mathrm{pH}$ や温度の変 化 ${ }^{25)}$ ，毒物 26,27)などに強いてとが報告されているが， これは好気処理の場合, 完全混合方式より, plug flow方式の方が環境変化に強いことからあ領ける.

汇材としては, 石英塊 ${ }^{8)}$ ，七ラミック製Raschig ringや, プラスチック球 ${ }^{28)}$, porous clay ${ }^{111}$, 孔をあ けたポリウレタン材291など，いろいろなあのが試みら れており，また塊状活性炭を詰めるとフェノール類が よく分解するてとが報告されている30〜32).

2 ）嫌気性流動沪床：エアリフトなどによって水流 をおこして担体を循環させる完全混合方式（Biological fluidized bed reactor, BFB)は,空気曝気 ${ }^{33-~}$ 36) や酸素曝気 ${ }^{371}$ 亿よる固定化活性污泥法として広く試 みられており, 無気的 (anoxic) におてなえば, 脱窒 素にあ使える ${ }^{38 \sim 41}$. 乙の方式を嫌気処理に用いたの が嫌気性流動沪床で, メタン菌のフォスファターゼ活 性とメタン生成活性の関係 ${ }^{42}$, 負荷 ${ }^{43)}$ や温度 ${ }^{44}$ 変動に 対する安定性などを在来型の完全混合方式と比較研究 するのに適している.酸生成槽とメタン発醅槽を分離 した 2 槽方式む試みられており ${ }^{45)}$, 上か開いた円錐形 のリアクターに，菌膜をつけた石炭粒を流動させて乳 清を嫌気処理する研究46)などあある. 流動床は完全混 合のモデル実験には最適だが, 強い水流を生じさせる ための電力消費量が多いのが難点と言えよう.

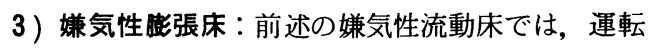


中は, 担体の占める容積が, 沈降時の倍以上になる. ての膨張を10〜20\%程度に留めるようにしたのが, anaerobic attached film expanded bed process (AAFEB)である. そのためには, 担体の比重を 1.02 1.2, 粒径を20〜 $30 \mu \mathrm{m}$, 廃水の流速を, $10 \sim 20 \mathrm{~mm} /$ 時ぐら いに設定すればよい。

つまり，上向流嫌気性沪床と嫌気性流動床の長所を 組み合わせたようなものになる，目づまりを気にせず に, 担体粒子をてまかく，固液接触面積を広くするて とができ, しかも電力が少くてすむ47,48)

4 ) 上向流嫌気性污泥ブランケット:オランダのWageningen農科大学のLettingaらによって考案された 方法である ${ }^{49 \prime}$. シリンダーに嫌気消化污泥を入れ，下 から上に向かって有機廃水をゆっくり流していると, 次第に污泥の粒状化が進み, 特に担体を加えなくても, 嫌気性膨張床のような様相になる。しかし, 洗い流し を防ぐため，上の方に広い余裕（blanket）を持たせ る必要があるので, upflow anaerobic sludge blanket process (UASB) と呼ばれる.

糖蜜廃液などの場合は単槽でよいが50), 一般には, 酸生成，ガス化の 2 槽建てにする方がよい51,52).また, 上端に内部沈嘱槽の役をする装置をつけたものや53), UASBの上に, その約半分の高さの充填材槽を重ねて, てまかい污泥粒を捕捉するようにした, UASB と上向 流嫌気性汇床の混合型などあ試みられている ${ }^{54)}$.

沪材を加えなくても "pelettization”ないし "natural immobilization”がおきる現象について，いろ いろと研究されているが55 57), 酢酸とプロピオン酸 を基質として $\mathrm{pH} 6$ で運転した時，生ずるペレットを走 查電顕でしらべると58), Methanothrix soehnge$n i i^{59)}$ 様の糸状メタン菌が, からまり合っているという.

5 ) 下向流嫌気性沪床：八ネ力ム型塔式撒水沪床に 廃水を満たして, ゆっくり流下させるようなもので, anaerobic downflow stationary fixed film (DS FF) reactor と呼ばれ, National Research Center of Canada で開発され $60 \sim 63)$, 農産廃棄物 ${ }^{64 ~ 66), ~}$ や産業廃水 ${ }^{67 \sim 69)}$ の処理にも効果を挙げている.

沪材としては, サンドペーパーで傷をつけた厚さ 3 $\mathrm{mm}$ のアクリル板で作った $2.4 \mathrm{~cm}$ 角の格子水路 ${ }^{70)}$ 同 じく磁性のあの ${ }^{71}$, needle-punched polyester ( $3 \mathrm{~m}$ $\mathrm{m}$ thickness, $280 \mathrm{~g} / \mathrm{m}^{2}$, Texel Inc., Beauce Nord, Quebec, Canada) biofilm support ${ }^{72,73)}$, red cley grain tile, gray potters clay formed into cylinder, Cloisonyl (a light polyvinyl ch- loride), etched glass ${ }^{73)}$ などが試みられている.

固定汇床の常として環境変化やショックロードに強 く ${ }^{72)}$, Geotextile (Texel Inc., $375 \mathrm{~g} / \mathrm{m}^{2}$ ) を用いた 場合, 走査電顕でしらべると, 汇材の表面がMethanosarcinaでおおおれていたという ${ }^{73)}$.

\section{2. 嫌気処理の微生物学}

ルーメンをはじめとする動物消化管内の嫌気性マイ クロフャラにくらべて, 非常におくれていたが, 最近, 嫌気処理槽や自然界の嫌気生物に関する研究が激増し ている.

1) 嫌気細菌：上向流嫌気性污泥ブランケットで, Methanothrixが58) 下向流嫌気性沪床でMethanosarcinaが ${ }^{73)}$ 優占生育していたてとは既述のとおりであ るが, 豚糞嫌気消化槽中の菌は, Peptostreptococcus, Eubacterium, Bacteroides, Lactobacillus, $\mathrm{Pe}$ ptococcus Clostridium, Streptococcus が主でBacteroides を除けば, 意外に, すべてグラム陽性菌であり, 消化産物は酢酸に収㪘するという ${ }^{74)}$. 木質廃物の嫌気消 化槽では, 最初 Methanosarcinaが多いが, 4 ケ月経過 後は, Methanothrix に変わって来た ${ }^{75)}$. 思いがけな いものとして，葡萄糖を基質とした集殖培養に於ける， 脂肪酸, 二酸化炭素, 水素の主な生産菌は Anaero $p$ las $m a$, 二酸化炭素之水素からのメタン生産菌は $M e$ thanoplasma, elizabethiiよ, いずれもマイコプラ

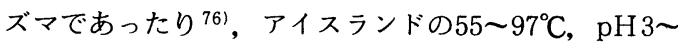
9 の温泉から, Thermoanaerobic ethanolicus,

Clostridium themoacetium, C. thermohydrosulfuricum などの新菌が得られたり ${ }^{77}$, 海の底泥から, メタノール, トリ, ジ, モノメチルアミンからメタン を生産し, 水素・二酸化炭素系には作用しない, オム スビ型の細胞から成る新属新種, Methanococcoides methylutens が分離されたり ${ }^{78)}$, 牛のルーメンから, キシラン, ペクチン, アラビノガラクタン等を分解す るスピロヘータ Trep்onemabryantiiが見つかった $り^{79)}$, 多くの新発見が続いている.

2 ) 嫌気性真菌：ニュージーランドの Cawthron Institute では, 牛や羊のルーメン内の嫌気性力ビ Neocallimastix frontalis の研究を進めている. 乙 れは, 棈円体の本体に, 分岐した根が生えたような形 でルーメン壁に貼りついたようなもので ${ }^{80)}$, 糖を発酵 し $^{81)}$, リグニンや ${ }^{82)}$, ヘミセルロース ${ }^{83)}$ を分解し, Methanospirillum hungates といっしょにいると, セルラーゼ生産性が向上し ${ }^{84)}$, Methanosarcina ba- 
rkeri およびMethanobrevibacter sp. と三者混合 塔養すると，セルロースをメタン化する ${ }^{85)}$.

今のとてろ, 嫌気消化装置からは, 嫌気性真菌や, ルーメンに居るような原虫などは見つかって居らず, てれらを接種する試みむ, これからの課題であろう.

\section{3. 環境毒等の生物処理}

文明生活に伴って排出されて環境を污染し, やがて は人体に害を及ぼす物質には，重金属や難分解性有機 化合物等がある.

1）重金属対策：硫酸還元菌が生産する硫化水素を 利用した重金属除去の研究は, 恐らく, 日本が最も進 んでいるが，欧米です，嫌気処理による産業廃水や861 廃棄処分地浸出水 ${ }^{871}$ からの重金属除去の研究がはじま っている. 尚, 硫酸還元菌による硫化水素生産は, メ タン発酵の敵とされて来たが, Desulfovibrio vulgaris 之Methanosarcina barkeri は, 水素移動に於い て協力関係化ある ${ }^{88)}$ 之か, 河口底泥中では, 硫酸イオ ンはメタノール, トリメチルアミン等のメタン化に, かえって促進的に作用するとか ${ }^{899}$, 沿岸底泥から, 0.1 $\mathrm{mM}$ 以上の硫化イオンの存在がメタン生成のための必 要条件であるような好熱性メタン菌が発見されたとか 90), フルフラールの嫌気分解に Desulfovibrio が主役 を演ずるなど91，硫酸還元菌の積極的評価につながる 研究が出て来ている.

2 ) PCB等の生分解 : イリノイ大学の Chakrabarty らは, プラスミド操作による炭化水素等の生分解 を扱って来たが 92 94), 塩化芳香族化合物 ${ }^{95 ~ 999, ~ そ の 一 ~}$ 端としてのPCB分解に成功している100,101! その個々 の成果あさることながら, 遺伝子工学を駆使した手法 に, 教科書的な意義があろう. PCB 102 1031やパラチオ ン104)の生分解などについては, 他にも多くの研究が ある.

3) 難分解性化合物の嫌気分解: 最後に, 嫌気処理 に戻ろう。海底堆積物による複雑な第 4 級アミンのメ タン化 ${ }^{105)}$, 嫌気性流動床 ${ }^{106)}$ 等によるクロロフェノー ル類の嫌気分解, 含窒素多環芳香族化合物のメタン化 110), フルフラールやグアヤコール1111, フタル酸エス テル112) 等の嫌気分解, 脱塩素, 開環, メタン生成とい う 3 つの型の菌の協力下に打ける, 3-クロロ安息香酸の メタン化 ${ }^{113)}$, 硫酸還元菌によるアントラニル酸の嫌気 分解 ${ }^{114), ~ ホ ゚ リ エ チ レ ン ク ゙ リ コ ー ル や 115) ト リ ハ ロ メ タ ~}$ ンは116)，嫌気的に扱う方が分解しやすいという報告 ${ }^{116)}$, 新しく考案した手法でしらべたとてろ,100種類の化学

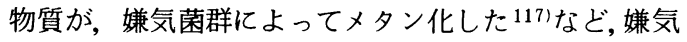
処理による環境浄化の将来に希望をいだかせる報告が 少くない。

尚，嫌気処理は硝化に結びつかないので，脱窒素に 関しては，画期的な技術の開発が期待される.

\section{引用 文 献}

1) Genung, R.K., and Pitt, W. W., Jr., "Deveropment of A Wastewater Treatment System Based on a FixedFilm Anaerobic Bior eactor." Proc. of the Seminar/ Workshop Anaerobic Filers: An Energy PIus for Wastewater Treatment, Jan. 9-10,1980, How ey -In-TheHills, Fla., ANL/CNSV-TM-50, 199 (1981).

2) Genung, R. K., et al., "Energy Conservation and Scale-Up Studies For A Wastewater Treatment System Based On a Fixed-Film Bioreactor." Biotechnol. Bioeng. Symp., 10, 295 (1980).

3 ) Koon, J. H., et al., "The Feasibility of An Anaerobic, Upflow, Fixed-Film Process for Treating Small Sewage Flows." Proc. U. S. Dept. of Energy, Energy Optimization of Water and Wastewater Management for Municipal and Industrial Applications Conf., Dec. 10-13, 1979, New Orleans, La. ANL/EES-TM-96, 1, 193 (1980).

4 ) U. S. Dept. of Energy, Proc. of the Seminar/Worksshop, Anaerobic Filters: An Energy Plus for Wastewater Treatment, Jan. 9-10, 1980, Howey-In-TheHills, Fla., ANL/CNSV-TM-50 (1981).

5 ) Ragan, J. L., "Celonese Experience with Anaerobic Filters." Proc. of thc Seminar/Workshop, Anaerobic Filters: An Energy Plus for Wastwater Treatment, Jan. 9-10, 1980, Howey-In-The-Hills, Fla., ANL/CN SV-TM-50, 129 (1981).

6 ) Jennett, J. C., and Rand, M. C., “A Comparison of Anaerobic vs. Aerobic Treatment of Phamaceutical Waste."Proc. of the Seminar/Workshop, Anaerobic Filters: An Energy Plus for Wastewater Treatment, Jan. 9-10, 1980, Howey-In-The-Hills, Fla., ANL/CNSVTM-50, 77 (1981).

7 ) Friedman, A. A., et al., "New Observation With Anaerobic Fixed Film Reactors." Proc. of the Seminar/ Workshop, Anaerobic Filters:An Energy Plus for Wastewater Treatment, Jan. 9-10, 1980, Howey-In-TheHills, Fla., ANL/CNSV-TM-50, 95 (1981).

8 ) Arora, H. C. and Chattopadhya, S. N.:Anaerobic contact filter prosess: a suitable method for the treatment of vegetable tanning effluents. Water Pollution control, 79(4), 501 506(1980).

9 ) Donovan, E. J., Jr., "Treatment of High Strength Wastes By An Anaerobic Filter." Proc. of the Seminar/ 
Workshop, Anaerobic Filters: An Energy Plus for Wastewater Treatment, Jan. 9-10, 1980, Howey-In-TheHills, Fla., ANL/CNSV-TM-50, 179(1981).

10) Hydroscience, Inc., "Pilot Scale Anaerobic Filter Treatment of Heat Treatment Liquor, Final Report." Report \# EPA-600/2 - 81- 114 (1981).

11) Wildenauer, F.X. and Winta, J. : Anaerobic digestion of high-strength acidic whey in a $\mathrm{pH}$-controlled upflow fixed film loop reactor. Appl. Microbiol. Biotechnol., 22(5), $367 \sim 372$ (1985).

12) Breure, A.M., Van Andel, J. G., Burger-Wiersma, T., Guijt, J. and Verkuijlen, J.: Hydrolysis and acidogenic fermentation of gelatin under anaerobic conditions in a laboratory scale upflow reactor. Appl. Microbiol. Biotechnol., 21 (1/2), 50 54(1985).

13) Hang, R.T., "Sludge processing to optimize digestibility and energy production." J. Water Pollut. Control Fed., 49, 1713 (July 1977).

14) Feliciano, D.V., "Bringing about an end to ocean dumping." J. Water Pollut. Control Fed., 53, 276 (March 1981).

15) Haug, R.T., et al., "Effect of themal pretreatment on digestibility and dewaterability of organic sludges." J. Water Pollut. Control Fed., 50; 73 (January 1978).

16) "Task II Report: Waste Activated Sludge Processing Studies for the Joint Water Pollution Control Plant." Los Angeles County Sanitation Districts (October 1976).

17) Haug, R.T., et al., "Anaerobic Filter Treats Waste Activated Sludge." Water and Sew. Works. (February 1977).

18) Vesilind, P.A., "Design of Prototype Thickeners from Batch Setteing Tests." Water and Sew. Work (July 1968).

19) Gossett, J.M., and McCarty, P.L., "Heat Treatment of Refuse for Increasing Anaerobic Biodegradability." Civil Engineering Tech. Rep. No. 192, Stanford Univer. (January 1975).

20) Garrison, W. E., and Horvath, R. W., "Parallel Evaluation of Belt Filter Presses and Low Speed Scroll Centrifuges." presented at Seventh U.S. and Japan Conf. on Sew. Treatment Technol., Tokyo, Japan. (May 1980).

21) LeBrun, T. J., and Tortorici, L., "Thermal Pretreatment Anaerobic Digestion Study." Report to the LA/ OMA Project by the Los Angeles County Sanitation Districts. (July 1978).

22) Trubiano, R. P., et al., "Pilot Studies of Municipal S1udge Dewatering Equipment." Rep. to the LA/OMA Project by the Los Angeles County Sanitation Districts (December 1980).

23) Haug, R. T., Le Braun, T. J. and Tortorici, L. D. : The- rmal pretreatment of sludges-a field demonstration. J. WPCF, 55, 23 34(1983).

24) Young, J. C., "Performance of Anaerobic Filters Under Transient Loading and Operating Conditions. "Proc. of the Seminar/Workshop, Anaerobic Filters: An Energy Plus for Wastewater Treatment, Jan. 9-10, 1980, HoweyIn-The-Hills, Fla., ANL/CNSV-TM-50, 159 (1981).

25) Speece, R. E., et al., "Methane Fermentation Toxity Response: Contact Mode." Proc. of the Seminar/Workshop, Anaerobic Filters: An Energy Plus for Wastewater Treatment, Jan. 9-10, 1980, Howey-In-TheHills, Fla., ANL/CNSV-TM-50, 11(1981).

26) Parkin, G. E., et al., "A Comparison of the Response of Methanogens to Toxicants: Anaerobic Filter vs. Suspended Growth Systems." Proc. of the Seminar/ Workshop, Anaerobic Filters: An Energy Plus for Wastewater Treatment, Jan. 9-10, 1980, HoweyIn-The-Hills, Fla., ANL/CNSV-TM-50, 37 (1981).

27) van den Berg, L., and Lentz, C. P., "Effects of Film Area To Volume Ratio, Film Support, Height, and Direction of Flow on Performance of Methanogenic Fixed Film Reactors." Proc. of the Seminar/Workshop, Anaerobic Filters: An Energy Plus For Wastewater Treatment, Jan. 9-10, 1980, Howey-In-TheHills, Fla., ANL/CNSV-TM-50, 1 (1981).

28) Braun, R.: Anaerobic filter treatment of molasses distillery slops. Water Res., 16 (7), 1167 1171(1982).

29) Frostell, B.: Anaerobic treatment in a sludge bed system compared with a filter system. Journal WP CF, 53 (2), $216 \sim 222$ (1981).

30) Cross, W. H., et al., "Anaerobic Activated Carbon Filters For the Treatment of Wastewaters Containing Phenols" Proc. of the Seminar/Workshop, Anaerobic Filters: An Energy Plus for Wastewater Management, Jan. 9-10, 1980, Howey-In-The-Hills, Fla , ANL/CNSV-TM-50, 59 (1981).

31) Khan, K. A., et al.,"Anaerobic Activated Carbon Filter For the Treatment of Phenol-Bearing Wastewater." J. Water Pollut. Control Fed., 53, 1519(1981).

32) Suidan, M. T., et al.,"Anaerobic Carbon Filter for Degradation of Phenols." J. Environ. Eng. Div., Proc. Am. Soc. Civ. Eng., 107, 563 (1981).

33) Jeris, J. S., et al.,"Secondary Treatment of Municipal Wastewater With Fluidized Bed Technology." in Biological Fluidized Bed Treatment of Water and Wastewater, P. F. Cooper and B. Atkinson (Eds.) Halsted Press. 112 (1981).

34) Wheeldon,D H. V., and Bayley, R. W.,"Economic Studies of Biological Fluidized Beds for Wastewater Treatment." in Biological Fluidized Bed Treatment of Water and Wastewater, P. F. Cooper and B. 
Atkinson (Eds.) Halsted Press, 306 (1981).

35) Nutt, S. G., et al., “Steady and Non-Steady State Performance of the Aerobic (Oxygenic) Biological Fluidized Bed," in Biologi cal Fluidized Bed Treatment of Water and Wastewater, P. F. Cooper and B. Atkinson (Eds.), Halsted Press 145 (1981).

36) Sehic, O. A.,"Fluidized Sand Recycle Reactor for Aerobic Biological Treatment of Sewage." in Biological Fluidized Bed Treatment of Water and Wastewater, P. F. Cooper and B. Atkinson (Eds.), Halsted Press, 179 (1981).

37) Sutton, P. M., et al., “Dorr-Oliver's Oxitron System ${ }^{\mathrm{TM}}$ Fluidized Bed Water and Wastewater Treatment Process," in Biological Fluidized Bed Treatment of Water and Wastewater, P. F. Cooper and B. Atkinson (Eds.), Halsted Press 285 (1981).

38) Hancher, C. W., Taylor, P. A. and Napier, J. M. Operation of a fluidized Bed bioreactor for denitrification. Biotechnol. Bioeng. Sympo., №. 8, 361 378 (1978).

39) Cooper, P. F., and Wheeldon, D. H. V. "Complete Treatment of Sewage in a Two Fluidized Bed Sys tem." in Biological Fluidized Bed Treatment of Water and Wastewater, P. F. Cooper and B. Atkinson (Eds.), Halsted Press, 121 (1981).

40) Francis, C. W., and Hancher, C. W."Biological Denitrification of High Nitrate Wastes Generated in the Nuclear Industry." in Biological Fluidized Bed Treatment of Water and Wastewater, P. F. Cooper and B. Atkinson (Eds.), Halsted Press (1981).

41) Gregory, R., and Sheiham, I., "Biological Fluidized-Bed Denitrification of Surface Water. The Economics of a Remedy for Nitrate in Drinking Water." in Biological Fluidized Bed Treatment of Water and Wastewater, P. F. Cooper and B. Atkinson (Eds.), Halsted Press, 329 (1981).

42) Bull, M. A., et al., "The Distridution of Bacterial Activity in an Anaerobic Fluidized Bed Reactor." Water Res. (G. B.), 18, 1017 (1984).

43) Barnes, D., et al., "Influence of Organic Shock Loads on the Performance of an Anaerobic Fluidized Bed Sytem." Proc. 38 th Ind. Waste Conf., Purdue Univer sity, Ann Arbor Sci. Publ., Ann Arbor, Mich., 715 (1984).

44) Kelly, C. R., and Switzenbaum, M. S., "Temperature and Nutrient Effects on the Anaerobic Expanded Bed Treating a High Strength Waste." Proc. 38 th Ind. Waste Conf., Purdue University, Ann Arbor Sci. Publ., Ann Arbor, Mich., 591 (1984).

45) Bull, M. A., Sterritt, R.M. and Lester, J. N. An Evaluation of single and separated phase anaerobic industrial wastewater treatment in fluidized bed reactors. Biotechnol. Bioeng., 26, 1054 1065(1984).

46) Boening, P. H. et al., : Anaerobic fluidized bed wheytreatment. Biotechnol. Bioeng., 24 (11), 2539 2556 (1982).

47) Switzenbaum, M. S. and Jewell, W. J.: The anaerobic attached film expanded bed reactor for the treatment of dilute organic wastes. U.S. Dept, of Energy Report TID-29398. Available from Natl. Tech. Information Service, U.S. Dept. of Commerce, Springfield Va. (1978).

48) Jewell, W. J., Switzenbaum, M. S. and Morris J. W.: Municipal wastewater treament with the anaerobic attached miorobial film expanded bed process. Journal WPCF, 53 (4), 482 490 (1981).

49) Lettinga, G., Van Velsen, A. F. M., Hobma, S. W., de Zeeuw, W. and Klapwijk, A.: Use of the upflow sludge blanket (USB) reactor concept for biological wastewater treatment, especially for anaerobic treatment. Biotechnol., Bioeng., 22, 699 734 (1980).

50) Pette, K. C., et al., "Full-Scale Anaerobic Treatment of Beet-Sugar Wastewater." In Proc. 35 th Ind. Waste Conf. (1980), Purdue Univ. (Ann Arobor Science Publishers, Inc., Ann Arbor, Mich.) 635 (1981).

51) Ghosh, S., "Advanced Two-Phase Digestion of Sewage Sludge." In "Symposium Papers: Energy From Biomass and Wastes VIII." D. L. Klass, (Ed.), Inst. Gas Technol., Chicago, III., 853 (1984).

52) Ghosh, S., et al., "Two-Stage Upflow Anaerobic Digestion of Concentrated Sludge." Biotechnol. Bioeng. Symp., 13 , 351 (1983).

53) Van Der Meer, R. R. and de Veeter, R.: Anaerobic treatment of wastewater: the gas-liquid-sludge separator. Journal WPCF, 54 (11), 1482 1492(1982).

$54)$ Guiot, S.R. and van den Berg, L.: Performance of an upflow anaerobic reactor combining a sludge blanket and a filter treating sugar waste. Bio technol, Bioeng., 27,800 806(1985).

55) Hulshoff Pol, L. W., J. de Zeeuw, C. T. M. Velzeboer and G. Lettinga. Granulation in UASB-reactors. Water Sci. Technol. 15:291-305(1983).

56) Hulshoff Pol, L. W., J. Dolfing,W. de Zeeuw, and G. Lettinga. Cultivation of well adapted pelltized methanogenic sludge. Biotechnol. Lett. 5:329-332 (1982).

57) Hulshoff Pol, L. W., J. Dolfing, K. van Straten, W. J. de Zeeuw, and G. Lettinga. Pelletization of anaerobic sludge in upflow anaerobic sludge bed reactors on sucrose containning substrates, p. 636 -642 , In M. J. Klug and C. A. Reddy(ed.). Current perspectives in microbial ecology. American Society for Microbiology, Washington, D. C.(1984). 
58) Brummeler, E.T. Pol, L. H. Delf ing. J. Lettinga, G., and Zehunder, 4. J. B., Methanogenesis in an upflow anaerobic sludge blanket reactor at pH6 on an acetate propionate mixture, Appl. Environ. Microbiol., $49(6), 1472-1477$ (1985).

59) Huser, B. A., K. Wuhrmann, and A. J. B. Zehnder. Methanothrix soengenii gen.. nov. sp. nov. a new acetotropic non-hydrogen oxidizing methannbacte:rium. Arch. Microbiol. 132:1-9. (1982).

60) K. J. Kennedy and L. van den Berg, "Effects of temperature and oveloading on the performance o of anaerobic fixed film reactors," Proceedings of the 36 th Purdue Industrial Waste Conference, La fayette. IN, 1981 , p. 678.

61) K. J. Kennedy and L. van den Berg, "Use of fixed film eactors for production of methane from waste," Proceedings of the Third Bioenergy Re.search and Development, Ottawa, Canada, 1981, p. 96 .

62) K. J. Kenedy and L. van den Berg, "Effect of height on the perfomance of anaerobic downflow stationary fixed film (DSFF) reactors treading bean blanching waste," 37 th Purdue Industrial Waste Conference, West Lafayette. IN, 1982, pp. 71-77.

63) K. J. Kennedy and R. L. Droste, "Effect of influent concentration on the start-up of anaerobic downfllow stationnary fixed film(DSFF) reactors, "Procedings of the 38 th Purdue Industrial Waste Conference, Lafayette, IN, May 1983.

64) Kennedy, K. J., and L. van den Berg. Cntinuous vs. slug loading of downflow stationary fixed film reactors digesting piggery waste. Biotechnol. Lett. $4: 137-142$.(1982).

65) Kennedy, K. J., and L., van den Berg. 1982. Anaetobic digestion of piggery waste using a stationary fixed film reactor. Agricultural Wastes $4: 151-158$. (1982).

66) Lo, K. V., A. J. Whithead, P. H. Liao, and N. R. Bulley. Methane production from screened dairy manure using a fixed film reactor. Agricultural Wastes 9:175-188. (1984).

67) Hall, E. R., B. E. Jank, and M. Jovanovic. 1981. Energy production from high strength industrial waste waster, p.125-129, In Proceedings of the Third Bioenergy Research and Development Seminar, Ottawa, Canada.(1981).

68) van den Berg, L., and K. J. Kennedy. Support materials for stationary fixed film reactors for highrate methanogenic fermentations. Biotechnol. Lett. 3:165-170. (1981).

69) van den Berg, L., K. J. Kennedy, and M. F.
Hamoda. Efect of type of waste on performance of anaerobic fixed film and upflow sludge bed cereactors. Proceedings of the 36 th Purdue Industrial Wast Conference, Layfayette, Ind. (1981).

70) Liao, P. H., and Lo, K. V.,: Methane production using whole and screened dairy manure in conventional and fixed film reactors. Biotechnol. Bioeng., $27,266 \sim 272$ (1985).

71) Samson, R. van den Bag, L. and Kennedy, K. J.: Mixing Characteristics and startup of anaerobic downflow stationary fixed film (DSFF) reactors Biotechnol. Bioeng., 27, 10 19(1985).

72) Kennedy, K. J., Muzar, M., and Copp. G.: Stability and performance of mesophilic anaerobic fixed-film reactors during organic overloading.

Biotechnol. Bioeng., 27, 86 93 (1985).

73) Harvey, M., Forsbag, C.W., Beveridge, T. J., Pos, J. and Ogilvie, J. R.,: Methanogenic activity and structural characteristics of the microbial biofilm on a needle punched polyster support. Appl. Environ. Microbiol., 48(3), $633 \sim 683$ (1984).

74) Lannotti, E.L., Fischer, J. R., and Sievers, D. M., Characterization of bacteria from a swine manure digester. Appl. Environ. Microbiol., 43(1), 136 143 (1982).

75) Zinder S. H., Cardwell, S. C., Anguish, T. Lee, M. and Koch, M.: Methanogenesis in a thermophilic $\left(58^{\circ} \mathrm{C}\right)$ anaerobic digestor, Metheno thrix sp. as an important aceticlastic methanogen. Appl. Environ. Microbiol., , 47(4), 796 807(1984).

76) Rose, C. S., and Pirt, J., “Converson of Glucose to Fatty Acids and Methane: Roles of Two Mycoplasmal Agents." J. Bacteriol., 147, 248(1981).

77) Ljungdahl. L. G., et al., Some Aspects of Thermophilic and Extreme Thermophilic Anaerobic Microorganisms." Trends Biol. Ferment., 18, 397(1981).

78) Sowers, K. R. and Ferry, J. G.: Isolation and Characterization of a methylotrophic marine methanogen Methenococcoides methylutens gen nov. sp. nov.

Appl. Environ Microbiol., 45(2), $684 \sim 690(1983)$.

79) Paster, B. J., and Canale-palola E.: Physiological diversity of rumen spirochetes; Appl. Environ. Microbiol., 43(3), 686 693(1982).

80) Banchop, T, : Rumen anaerobic fungi of cattle and sheep. Appl. Environ. Microbiol, 38(1), 148 $158(1979)$.

81) Mountfort, D. and Asher, R. A.; Role of catabolite regulatory mecanisms in control of carbohydrate utilization by the rumen anaerobic fungus Neocallimastix frontalis. Appl. Environ. Microbiol., 46(6) 
$1331 \sim 1338$ (1983).

82) Windham, W. R. and Akin, D.E.: Rumen fungi and forage fiber degradation. Appl. Environ. Microbiol., 48(3), 473 476(1984).

83) Perce, P.P. and Banchop, T.: Glycosidases of the rumen anaerobic fungus Neocallimastix frontalis grown on cellulosic substrates. Appl. Environ. Microbiol., 49(5), 1265 1269(1985).

84) Mountfort, D. O. and Asher, R.A. : Production and regulation of cellulose by two strains of the rumen anaerobic fungus Neocallimasix frontalis. Appl. Environ. Microbiol., 49(5), 1314 1322 (1985).

85) Mountfort, D. O., Asher, R. A, and Banchop, T.: Fermentatation of cellulose to methane and carbon dioxide by a rumen anaerobic fungus in a triculture with Methanobrevibacter sp. strain RAI and Methanosarcima barkeri, Appl. Environ., Microbiol., 44 (1), $128 \sim 134$ (1982).

86) Plahl-Wabnegg, E. u. Kross, H.: Biologische Schwermetallentfernung bei Indstrieabwassern. gwf-Wasser /Abwasser. 125, H.9, 424 426(1984).

87) Cameron. R. D. et al,: Trace methods and anearobic digesion of leachate. Journal WPCF, $52(2), 28$ $282 \sim 292$ (1980).

88) Hatchikan, C. E., Le Gall, J. and Belaich, J.: Ener getics of growth of a defined mixed culture of $\mathrm{D}$ Desulfovibrio vulgaris and Methanosarcina barkeri: interspecies hydrogen transfer in batch and continuous cultures, Appl. Environ. Microbiol., 46 (5), $1152 \sim 1156$ (1983).

89) Oremland, R.S. and Polcin, S.: Methanogenesis and sulfate reduction: competitive and noncompetitive substrates in estuarine sediments. Appl. Environ. Microbiol. 44(6), 1270 1276 (1982).

90) Ronnow, P. H., and Gunnarsson, L. A. H., "Sulfide-Dependent Methane Production and Growth of a Thermophilic Methanogenic Bacterium." Appl. Environ. Microbiol., 42, 580, (1981).

91) Srune, G., Schoberth, S. M, and Sahm: H,: Growth of a strictly anaerobic bacterium on furfural (2-furaldehyde). Appl.Environ Microbiol., 46(5), $1187 \sim 1192$ (1983).

92) Chakrabarty, A. M.: Plasmids in Pseudomonas. Annu. Rev. Genet. $10: 7-30$. (1976).

93) Farrell, R., and A. M. Chakrabarty: Degradative plasmids: molecular nature and mode of evolution, p. 97-109. In K. N. Timmis and A. Puhler (ed.), Plasmids of medical, environmental and commer cial importance. Elsevier/North-Holland Publishing Co., Amsterdam. (1979).
94) Chakrabarty, A.M.: Plasmids and dissimilation of synthetic environmental pollutants, p. 21-30. In C. Stuttard and K. R. Rozee (ed.), Plasmids and transposons: enviromental effects and maintenance mechanisms. Academic Press, Inc., New York.(1980).

95) Chatterjee, D. K., S. T. Kellogg, D. R. Watkins and A. M. Chakrabarty: Plasmids in the biodegradation of chlorinated aromatic compounds, p. 519-528. In S. B. Levy, R. C. Clowes, and E. L. Koenig (ed.), Molecular biology, pathogenicity and ecology of bacterial plasmids, Plenum Publishing Corp., New York.(1981).

96) Kilbane, J. J., D. K. Chatterjee, J. S. Karns, S. T. Kelogg, and A. M. Chakrabarty: Biodegradation of 2,4,5-trichlorophenoxyacetic acid by a pure culture of Pseudomonas cepacia. Appl. Environ. Microbiol. 44: 72 -78. (1982).

97) Karns, J. S., J. J. Kilbane, S. Duttagupta, and A. M Chakrabarty: Metabolism of halophenols by 2,4,5trichlorophenoxyacetic acid-degrading Pseudomonas cepacia. Appl. Environ. Microbiol. 46 :1176-1181. (1983).

98) Kilbane, J. J., D. K. Chat terjee, and A. M. Chakraharty: Detoxification of 2,4,5-trichlorophenoxyacetic and from contaminated soil by Pseudomonas cepacia. Appl. Environ. Microbiol. 45 :16971700 . (1983).

99) Karns, J. S., Kilbane, J. J., Duttagupta, S. and Chakrabarty, A. M.: Metabolism of halophenols by 2, 4,5-trichloro phenoxyacetic acid-degrading Pseudomonas cepacia. Appl. Environ. Microbiol., $46(5), 1176 \sim 1181$ (1983).

100) Kamp, P. F., and A. M. Chakrabarty: Plasmids specifying $\mathrm{p}$-chlorobiphenyl degradation in enteric bacteria, p. 275-285. In K. N. Timmis and A. Puhler (ed.), Plasmids of medical, environmental and commerical importance. Elsevier/North-Holland Publish ing Co., Amsterdam. (1979).

101) Furukawa, K. and chakrabarty, A. M.: Involvement of plasmids in total degradation of chlorinated biphenyl., Appl. Environ. Microbiol., 44 (3), 619 626 (1982).

102 ) Masse, R., Messier, F., Peloquin, L., Ayotte, C. and Sylvestre, M.: Microbial biodegradation of 4 chlorobiphenyl, a model compound of chlorinated biphenyls. Appl. Environ. Microbiol, 47 (5), 947 951 (1984).

103 ) Sylvestre, M., Masse, R., Ayotte, C., Messier, F. and Fauteux, J.: Total biodegradation of 4-chlorobiphenyl $(4 \mathrm{CB})$ by a two-membered bacterial culture. Appl. Microbiol. Biotechnol., 21, 192 195 
(1985),

104 ) Reddy, B. R. and Sethunathan, N.: Mineralization of parathion in the rice rhizosphere. Appl. Environ. Microbiol., 45 (3), 826 829 (1983).

105) King, G. M., “Metabolism of Trimethylamine, Chol line, and Glycine Betaine by Sulfate-Reducing and Methanogenic Bacteria in Marine Sediments." Appl. Environ Microbiol., 48,719 (1984).

106) Mosey, F. E., "Anaerobic Biological Treament of Food Industry Wastewaters." Water Pollut. Control (G. B.), 80, 273(1981).

107) Boyd, S. A. and Shelton, D. R.; Anaerobic biodegradation of chlorophenols in fresh and acclimated sludge. Appl. Environ. Microbiol., 74 (2), $272 \sim 277$ (1984).

108) Boyd, S. A., Shelton, D. R., Berry, D. and Tiedje, T. M.: Anaerobic biodegradetion of phenolic compounds in digested sludge. Appl. Environ. Microbiol., 46 (1),50 54 (1983).

$109)$ Boyd, S. A., and Shelton, D. R., "Anaerobic Biodegradation of Chlorophenols in Fresh and Acclimated Sludge." Appl. Environ. Microbiol., 47, 272 (1984).

110) Wang, Y. T., et al., “Anaerobic Biodegradation of Indole to Methane," Appl. Environ. Microbiol., 48, 1058 (1984).
111 ) Benjamin, M. M., et al., "Anaerobic Toxicity and Biodegradability of Pulp Mill Waste Constituents. Water Res. (G. B.), 18, 601 (1984).

112 ) Shelton, D. R., et al., “Anaerobic Biodegradation of Phthalic Acid Esters in Sludge." Environ. Sci. Technol., 18, 93 (1984).

113 ) Shelton, D. R., and Tiedje, J. M., "Isolation and Partial Characterization of Bacteria in an Anaerobic Consotium That Mineralizes 3-Chlorobenzoic Acid." Appl. Environ. Microbicl., 48, 840 (1984).

114 ) Balba, M. T. M., et al., “Anaerobic Metabolism of Aromatic Compounds by Microbial Associations Isolated from Saltmarsh Sediment." Biochem. Soc. Trans., 9,230(1981).

$115)$ Dwyer, D. F. and Tiedje, J. M.: Degradation of ethylene glycol and polyethylene glycols by methanogemic consortia. Appl. Environ. Microbiol., 46(1), 185 190(1983).

116) Bouwer, E. J., et al., "Anaerobic Degradation of Halogenated 1 -and 2-Carbon Organic Compounds." Environ. Sci. Technol., 15, 596(1981).

117 ) Shelton, D. R., and Tiedje, J. M., “General Me thod for Determining Anaerobic Biodegradation Potential." Appl. Environ. Microbiol., 47, 850 (1984).

最新刊図書

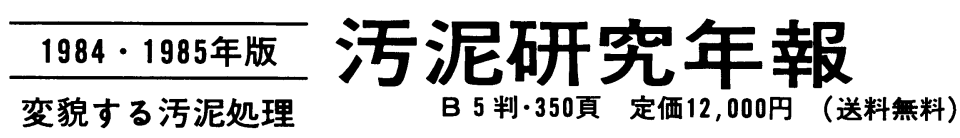

執筆者：京都大学 平 岡 正勝 日本下水道事業団 栗 林 宗人他 40 名

\section{主な内容}

\section{第 1 童 変貌する污泥処理技術}

第 1 節 総 括

第 2 節 濃縮

第 3 節 嫌父性消化システム

第 4 節 脱水

第 5 節 乾燥 - 焼却

第 6 節 溶融

第 7 節 コンポスト

第 8 節 港湾底質処理技術

第 2 章各省庁における污泥処理・ 処分研究開発の現状と展望

第 1 節 建設省における污泥処理. 処分研究開発の現状と展望
第 2 節 通商産業省における污泥 処理処分研究開発の動们

第 3 節 厚生省に扔ける污泥処理 処分研究開発の動问

第 4 節 運輸省における污泥処理 処分の研究開発の現状と展望

第 5 節 農林水産省における污泥 処理処分の研究開発の現状と展望

第 3 章 污泥研究レビュー

1. 日本における污泥研究論文

2. 外国における污泥研究論文

第 4 章 污泥に関する主要論交概要
一既刊污泥年報 1983污泥年報 定価 9,000円 主要テーマ: 污泥からの工 ネルギー回収, 資源化及び都 市ごみと下水污泥の混合処理

1982污泥年報（在庫切れ） 1981污泥年報 定価 6,000円 主要テーマ: 省エネ下の污 泥処理

1980污泥年報 定価 5,000円 主要テーマ: 污泥の脱水技術

申込先 干550 大阪市西区京町堀 1-14-25(京ニビル) TEL06-443-6445 環境技術研究会 